\title{
Molecular and Histopathological Evidence of Mycobacteriosis in Paradise Fish Macropodus opercularis Imported into Korea
}

\author{
Hyun-Ja Han ${ }^{1, a}$, Jeong-Ho Kim², Chan-Hyeok Jeon², Wi-Sik Kim ${ }^{3}$ Do-Hyung Kim ${ }^{1}$, Sung-Ju Jung ${ }^{1}$ and \\ Myung-Joo Oh ${ }^{1 *}$ \\ ${ }^{1}$ Department of Aqualife Medicine, Chonnam National University, Yeosu 550-749, Korea \\ ${ }^{2}$ Faculty of Marine Bioscience and Technology, Gangneung-Wonju National University, Gangneung 210-702, Korea \\ ${ }^{3}$ The Fisheries Science Institute, Chonnam National University, Yeosu 550-901, Korea \\ aPresent address: Aquatic Life Disease Control Division, Fundamental Research Department, National Fisheries Research and \\ Development Institute, Busan 619-705, Korea
}

\begin{abstract}
We report on mycobacteriosis in an imported tropical ornamental fish Macropodus opercularis commonly known as the paradise fish. Mass mortality occurred in paradise fish imported to Korea from Southeast Asia in 2008. The affected fish did not show any outward clinical signs, but enlargement of the spleen, kidneys, and liver was observed on dissection. Histopathological examination revealed numerous granulomas in the spleen, and acid-fast bacilli were observed in the centers of the granulomas. About $65 \%$ of spleen DNA samples were PCR positive using mycobacteria-specific primers targeting the $16 \mathrm{~S}$ rRNA and $h s p 65$ genes. The nucleotide identities of the 16S rRNA and hsp65 genes with those of Mycobacterium marinum were 99.5\% and 99.4\%, respectively. Although the bacterium was not cultured, the molecular diagnosis and histopathological findings were consistent with mycobacteriosis in paradise fish.
\end{abstract}

Key words: Paradise fish, Macropodus opercularis, Piscine mycobacteriosis, Histopathology, Korea

\section{Introduction}

Mycobacteria are pleomorphic, aerobic, Gram-positive, acid-fast, non-motile rods, $0.2-0.6 \mu \mathrm{m}$ in diameter and 1-10 $\mu \mathrm{m}$ long in the genus Mycobacterium, the only genus in the family Mycobacteriaceae (Gauthier and Rhodes, 2009). The Mycobacterium comprises obligate pathogens that cause serious human and animal diseases, opportunistic pathogens, and saprophytic species (Bland et al., 2005).

Piscine mycobacteriosis is a systemic infectious disease that is typically a subacute to chronically progressive condition caused by different Mycobacterium species, including Mycobacterium marinum, $M$. fortuitum, M. chelonae, and $M$. abscessus (Kusunoki and Ezaki, 1992; Decostere et al., 2004).
More recently, additional mycobacterial species have been implicated as the causes of mycobacterial infections, including M. shottsii, M. montefiorense, and M. haemophilum (Levi et al., 2003; Rhodes et al., 2003; Whipps et al., 2007). Although mycobacteriosis is usually a chronic disease and may not produce external lesions, the internal lesions typically include enlargement and typical grey or white nodules of the spleen, kidneys, and liver (Chinabut, 1999; Gauthier and Rhodes, 2009).

This study reports on mycobacteriosis in an imported tropical ornamental fish, Macropodus opercularis, commonly known as the paradise fish.
Open Access http://dx.doi.org/10.5657/FAS.2013.0165

This is an Open Access article distributed under the terms of the Creative Commons Attribution Non-Commercial License (http://creativecommons. org/licenses/by-nc/3.0/) which permits unrestricted non-commercial use, distribution, and reproduction in any medium, provided the original work is properly cited. pISSN: 2234-1749 eISSN: 2234-1757
Received 5 February 2013; Revised 24 May 2013

Accepted 17 June 2013

*Corresponding Author

E-mail: ohmj@chonnam.ac.kr 


\section{Materials and Methods}

\section{Disease outbreak and fish sampling}

Forty paradise fish (body weight, $1.8 \pm 0.4 \mathrm{~g}$ ) were bought from an ornamental fish wholesaler in Korea in June 2008. After 2 days of acclimation, the first fish death was recorded, and all of the fish died by July (cumulative mortality rate, approximately $100 \%$ per month). Few of the diseased fish showed any external signs, but enlargement of the spleen and discoloration of the liver were observed after postmortem examination. Moribund and freshly killed fish were examined using histopathology and microbial cultures after euthanasia with excessive 2-phenoxyethanol (Sigma, St Louis, MO, USA). The gill and body surfaces were examined microscopically for the presence of parasites.

\section{Histopathology}

The spleen was collected from five moribund fish and fixed immediately in $10 \%$ neutral buffered formalin. After fixation, standard histological procedures were used for tissue dehydration and paraffin embedding. Tissue sections were stained with hematoxylin and eosin (H\&E) and Ziehl-Neelsen (ZN).

\section{Bacterial examination}

The liver, kidney, and spleen of moribund and freshly killed fish were inoculated into tryptone soy agar (TSA; Difco, Sparks, MD, USA) and incubated at $30^{\circ} \mathrm{C}$ for $72 \mathrm{~h}$. Frozen kidney and spleen tissues were homogenized in sterile $0.85 \%$ saline $(\mathrm{w} / \mathrm{v})$, decontaminated with $0.35 \%$ hexadecylpyridinium chloride for $30 \mathrm{~min}$, and then centrifuged at 2,800 $\mathrm{g}$ for 30 min (Corner and Trajstman, 1988). The supernatant was removed, and the sediment was washed twice with $1 \mathrm{~mL}$ of sterile phosphate-buffered saline (PBS). The sediments were inoculated on Middlebrook $7 \mathrm{H} 10$ (Difco), and the medium was incubated aerobically at $30^{\circ} \mathrm{C}$ and checked daily for 2 months. Before decontamination, samples were also cultured in TSA (Difco) to detect common bacterial fish pathogens and incubated for $72 \mathrm{~h}$ at $30^{\circ} \mathrm{C}$.

\section{Molecular diagnosis}

For PCR, genomic DNA was extracted from frozen spleen stored at $-80^{\circ} \mathrm{C}$ using an AccuPrep Genomic DNA purification kit (Bioneer, Daejeon, Korea). Molecular detection of Mycobacterium species was based on $16 \mathrm{~S}$ ribosomal DNA (16S rRNA) and 65-kDa heat-shock protein-encoding gene ( $h s p 65$ ) sequences. The primers for the 16S rRNA (T39 and T13; PCR product size, 924 bp) (Talaat et al., 1997) and hsp65 (Tb11 and Tb12; PCR product size, 441 bp) (Aranaz et al., 2008) genes were used for amplification and sequencing. The DNA was amplified with an initial 5 -min denaturation at $95^{\circ} \mathrm{C}$, followed by 35 cycles of $94^{\circ} \mathrm{C}$ for $30 \mathrm{~s}, 55^{\circ} \mathrm{C}$ (for $16 \mathrm{~S}$ rRNA) or $58^{\circ} \mathrm{C}$ (for $h s p 65$ ) for $30 \mathrm{~s}$, and $72^{\circ} \mathrm{C}$ for $1 \mathrm{~min}$, with a final 5-min extension at $72^{\circ} \mathrm{C}$. The sequencing reactions were carried out with a BigDye terminator ver. 1 cycle sequencing kit (Applied Biosystems, Foster City, CA, USA), and the products were sequenced on an ABI PRISM 3130xl Genetic Analyzer (Applied Biosystems). 16S rRNA and hsp65 DNA sequences for Mycobacterium species available from GenBank plus our sequences were aligned using ClustalX ver. 1.83 (Thompson et al., 1997). Phylogenetic trees were obtained using the neighborjoining method with Kimura's two-parameter distance correction model with 1,000 bootstrap replications using MEGA ver. 4 (Tamura et al., 2007).

\section{Results}

\section{Histopathology}

Granulomas 20-57 $\mu \mathrm{m}$ in diameter were observed in the H\&E-stained spleen sections of all individuals examined (Fig. 1A). Numerous granulomas appeared in the splenic pulp and sheathed tissue (Fig. 1A and 1B). Severe necrosis was observed in the central eosinophilic area of the granulomas, surrounded by extensive fibrous infiltration containing several layers of epithelioid cells (Fig. 1B). When stained with ZN, numerous acid-fast bacilli were found in the centers of the granulomas in the spleen (Fig. 2).

\section{Bacterial examination}

Two fast-growing bacteria, Citrobacter freundii and Pseudomonas sp., grew on TSA, but they were isolated from one fish only. Histopathological examination led us to suspect mycobacteriosis, so we attempted bacterial isolation using Middlebrook 7H10 from frozen paradise fish tissue. However, no mycobacterial growth was observed after incubation for 2 months.

\section{Molecular diagnosis}

Thirteen (62\%) and $14(67 \%)$ of 21 fish were positive for mycobacteriosis, determined by PCR targeting the 16S rRNA and $h s p 65$ genes, respectively. All of the samples positive for the 16S rRNA gene were also positive for the hsp65 gene. Analysis of the 16S rRNA (838-bp product) and hsp65 (380bp product) DNA sequences revealed the greatest similarity with those of Mycobacterium marinum retrieved from the NCBI database (GenBank accession nos. AF456239 [16S rRNA] and AF456471 [hsp65]). Phylogenetic trees based on the $16 \mathrm{~S}$ rRNA and hsp65 genes showed that the strains isolated in this study were related most closely to M. marinum (Fig. 3). The nucleotide identities of the 16S rRNA and hsp65 genes with those of M. marinum (M. shottsii) were 99.5\% (99.4\%) 
Han et al. (2013) Mycobacterial Infection in Paradise Fish
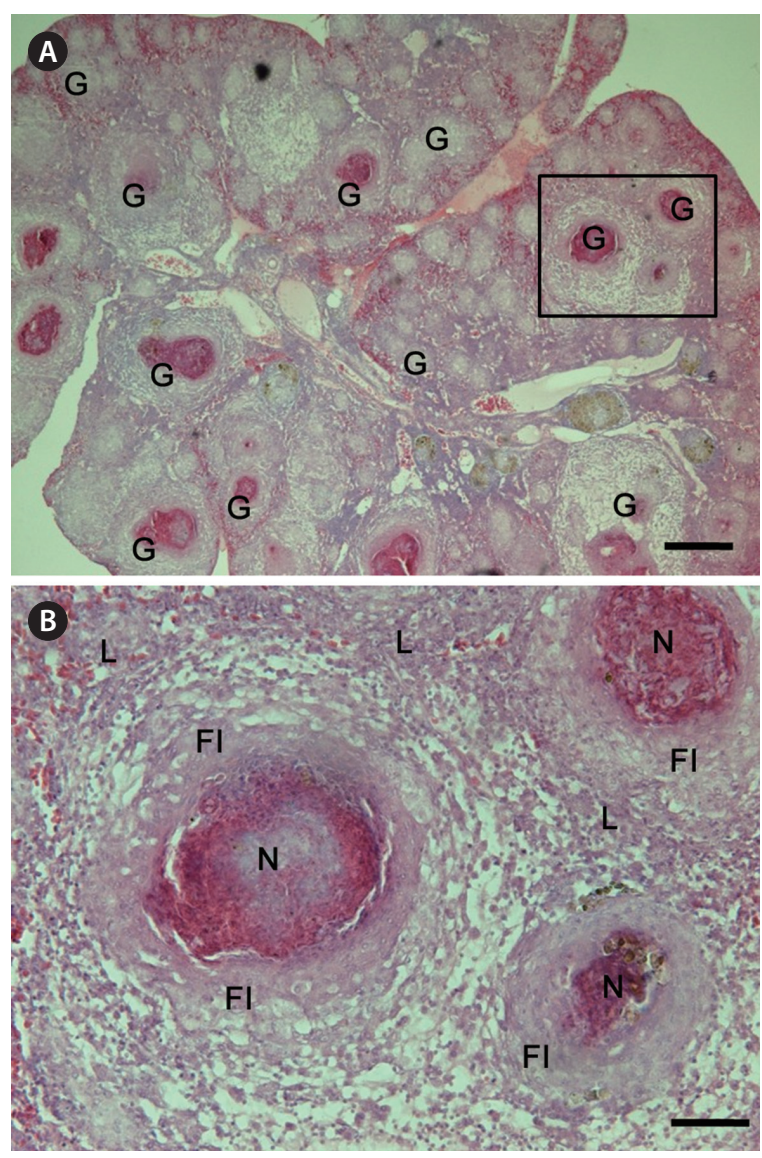

Fig. 1. Histopathology of mycobacteriosis in Macropodus opercularis. (A) Numerous granulomas are present in spleen of diseased fish. G, granulomas. (B) Higher magnification of a square in (A) showing granuloma morphology. Fibrosis (FI) of the granulation tissue containing epithelioid cells. $\mathrm{N}$, necrotic core; L, lymphocyte. Haematoxylin-eosin stain. Scale bars: $\mathrm{A}=$ $200 \mu \mathrm{m}, \mathrm{B}=50 \mu \mathrm{m}$.

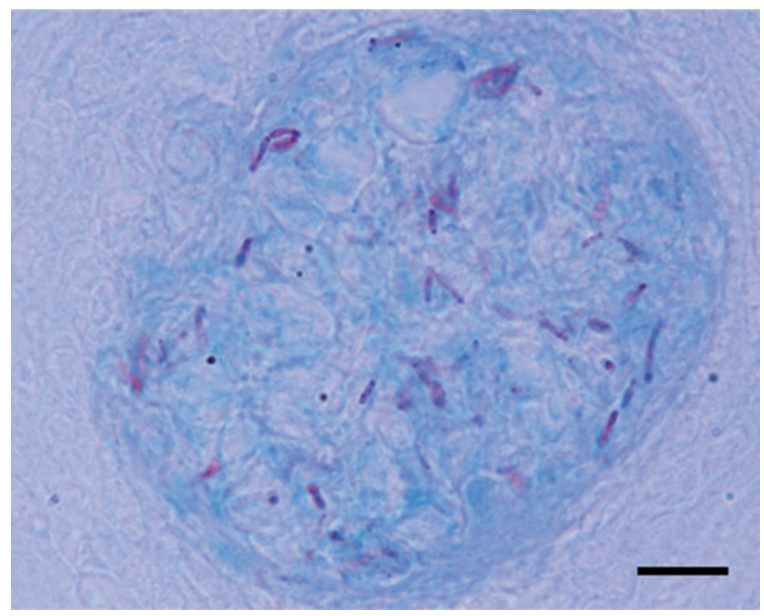

Fig. 2. Mycobacteria infecting Macropodus opercularis. Ziehl-Neelsen stain of a section from spleen of diseased fish. Numerous acid-fast bacilli are present in the center of granuloma. Scale bar $=10 \mu \mathrm{m}$. and $99.4 \%(99.1 \%)$, respectively.

\section{Discussion}

Several Mycobacterium species have been identified as ornamental fish pathogens (Lescenko et al., 2003). The paradise fish is also susceptible to Mycobacterium infection. For example, Gómez (2008) found granulomatous inflammation and numerous acid-fast bacteria in tissue sections of granulomas from a diseased paradise fish, but the causative agent was not confirmed at the species level. Additionally, Marcì et al. (2008) reported M. fortuitum infection in severely emaciated paradise fish, with ascites and granulomas of various sizes in the internal organs. In our study, the $16 \mathrm{~S}$ rRNA and $h s p 65$ gene analysis show that the amplified genes were related most closely to M. marinum. However, it is difficult to distinguish among M. marinum, M. shottsii, M. pseudoshottsii, and M. ulcerans using $16 \mathrm{~S}$ rRNA and $h s p 65$ gene sequences (Adekambi and Drancourt, 2004). Additional research to identify the $M y$ cobacterium sp. infecting the paradise fish is needed.

We could not culture Mycobacterium sp. from paradise fish, as freezing the spleens and kidneys affected the viability of the mycobacteria, resulting in negative cultures on Middlebrook $7 \mathrm{H} 10$. Although bacterial isolation is considered the gold standard for diagnosing bacterial disease, the isolation of mycobacteria from field samples is generally problematic and sometimes not even attempted because mycobacteria are slow-growing fastidious organisms, and isolation can be adversely affected by other microbial contamination (Pate et al., 2005). Instead, mycobacteria have been detected by amplifying various target genes, such as 16S rRNA, IS986, IS611, and hsp65 (Kolk et al., 1992; Telenti et al., 1993; Kox et al., 1995; Noordhoek et al., 1995), and PCR has been used to detect mycobacterial infection in several studies (Frevel et al., 1999; Astrofsky et al., 2000). In our study, PCR amplification targeting the $16 \mathrm{~S}$ rRNA and $h s p 65$ genes was carried out, and more than $60 \%$ of the examined fish showed positive reactions for both genes. However, the sensitivities of the 16S rRNA and $h s p 65$ PCR primers may differ, and the $h s p 65$ PCR primers may have been more sensitive than the 16S rRNA PCR primers in this study.

Although mycobacteriosis was confirmed in imported paradise fish, the etiological agent of the mass mortality is unclear, as Mycobacterium sp. was detected only in about $65 \%$ of the fish by PCR, and megalocytivirus (10\%, four of 40 fishes) and reovirus (30\%, three of 10 fishes) were also detected in the diseased paradise fish by PCR (data not shown). Further studies of the pathogenicity in paradise fish are necessary. However, our results suggest that mass mortality in paradise fish was caused by multiple infections with Mycobacterium sp., megalocytivirus, and reovirus.

Over 1 billion ornamental fish are traded internationally each year (Whittington and Chong, 2007). Paradise fish are 

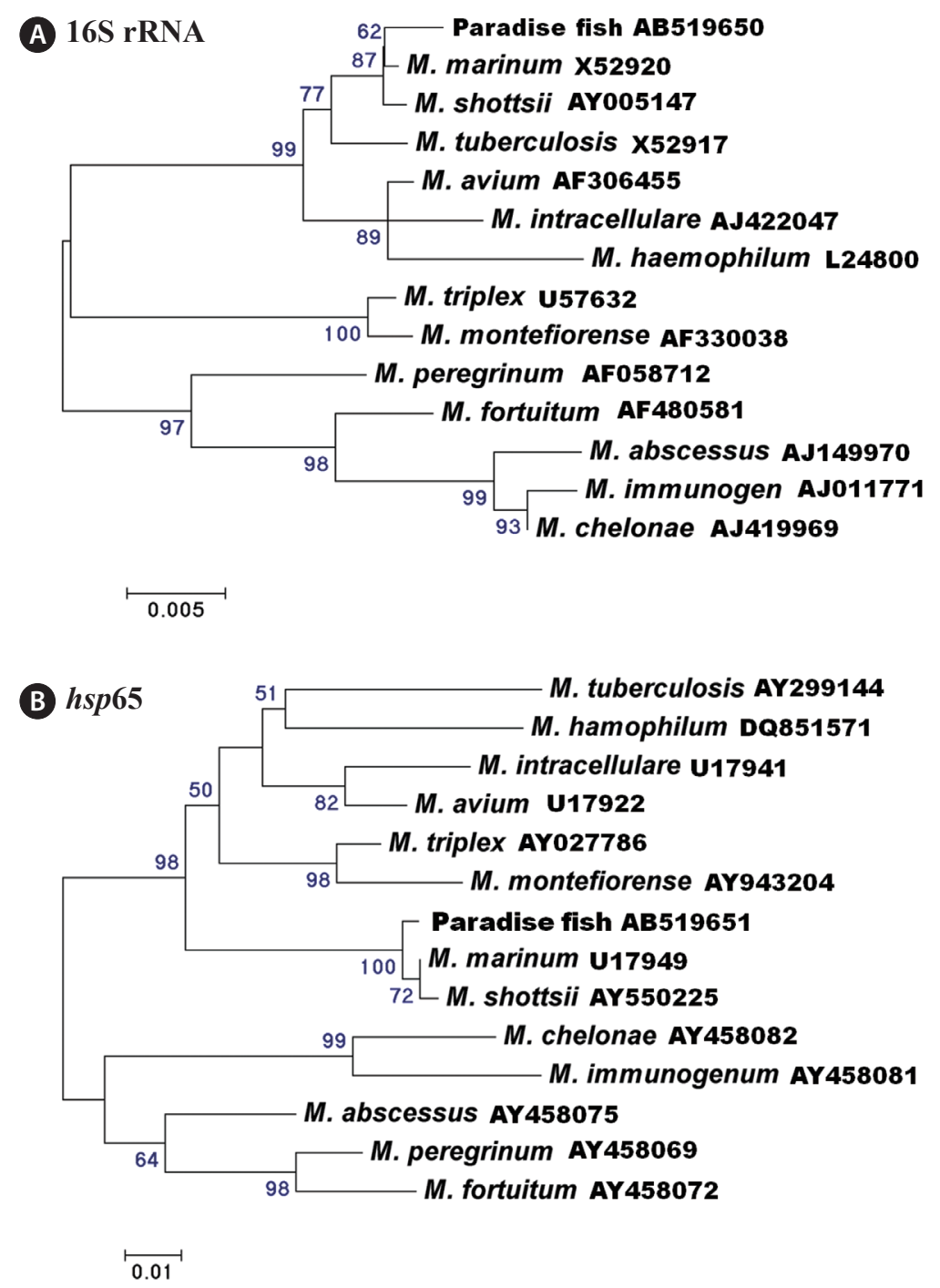

Fig. 3. Neighbor-joining analysis of Mycobacterium species $16 \mathrm{~S}$ rRNA (A) and $h s p 65$ (B) sequences from GenBank.

small freshwater labyrinth fish found in ditches and paddy fields in Southeast Asia (Man and Hodgkiss, 1981). Paradise fish are imported into Korea from Indonesia, Malaysia, and Vietnam (National Fisheries Products Quality Inspection Service, personal communication), but there are no clear guidelines or checks on paradise fish suspected of having mycobacteriosis. This is made more difficult given the lack of obvious signs of sickness in diseased fish. In this study, it is likely that the paradise fish monitored were infected before importation to Korea, as mortality occurred during the acclimation period, and mycobacteriosis is generally a chronic, slowly developing disease.

In conclusion, we confirmed the presence of mycobacteriosis in paradise fish imported from Southeast Asia into Korea. Considering the broad host spectrum of Mycobacterium sp. and increasing global international trade in ornamental fish, stricter quarantine inspection guidelines are necessary to reduce the risk of mycobacteriosis in fish in Korea.

\section{Acknowledgements}

The current work was supported by the Technology Development Program for Fisheries, Ministry for Food, Agriculture, Forestry and Fisheries, Republic of Korea.

\section{References}

Adékambi T and Drancourt M. 2004. Dissection of phylogenetic relationships among 19 rapidly growing Mycobacterium species by 16S rRNA, $h s p 65$, sodA, recA and rpoB gene sequencing. Int $\mathrm{J}$ 
Syst Evol Microbiol 54, 2095-2105. http://dx.doi.org/10.1099/ ijs.0.63094-0.

Aranaz A, Gibello A, Álvarez J, Mata AI, Rodríguez A, Fallola C, Fernández-Garayzábal JF and Domínguez L. 2008. Mycobacterium peregrinum infection in farmed European tench (Tinca tinca L.). Vet Microbiol 131, 393-399. http://dx.doi.org/10.1016/j.vetmic.2008.04.017.

Astrofsky KM, Schrenzel MD, Bullis RA, Smolowitz RM and Fox JG. 2000. Diagnosis and management of atypical Mycobacterium spp. infections in established laboratory zebrafish (Brachydanio rerio) facilities. Comp Med 50, 666-672.

Bland CS, Ireland JM, Lozano M, Alvarez ME and Primm TP. 2005. Mycobacterial ecology of the Rio Grande. Appl Environ Microbiol 71, 5719-5727. http://dx.doi.org/10.1128/AEM.71.10.57195727.2005 .

Chinabut S. 1999. Mycobacteriosis and nocardiosis. In: Fish Diseases and Disorders. Vol. 3. Viral, Bacterial and Fungal Infections. Woo PTK and Bruno DW, eds. CABI Publishing, Wallingford, GB, pp. 319-340.

Corner LA and Trajstman AC. 1988. An evaluation of 1-hexadecylpyridinium chloride as decontaminant in the primary isolation of Mycobacterium bovis from bovine lesions. Vet Microbiol 18, 127134. http://dx.doi.org/10.1016/0378-1135(88)90058-2.

Decostere A, Hermans K and Haesebrouck F. 2004. Piscine mycobacteriosis: a literature review covering the agent and the disease it causes in fish and humans. Vet Microbiol 99, 159-166. http:// dx.doi.org/10.1016/j.vetmic.2003.07.011.

Frevel T, Schäfer KL, Tötsch M, Böcker W and Dockhorn-Dworniczak B. 1999. PCR based detection of mycobacteria in paraffin wax embedded material routinely processed for morphological examination. Mol Pathol 52, 283-288. http://dx.doi.org/10.1136/ mp.52.5.283.

Gauthier DT and Rhodes MW. 2009. Mycobacteriosis in fishes: a review. Vet J 180, 33-47. http://dx.doi.org/10.1016/j.tvj1.2008.05.012.

Gómez S. 2008. Prevalence of microscopic tubercular lesions in freshwater ornamental fish exhibiting clinical signs of non-specific chronic disease. Dis Aquat Org 80, 167-171. http://dx.doi. org/10.3354/dao01939.

Kolk AHJ, Schuitema ARJ, Kuijper S, van Leeuwen J, Hermans PWM, van Embden JDA and Hartskeerl RA. 1992. Detection of Mycobacterium tuberculosis in clinical samples by using polymerase chain reaction and a nonradioactive detection system. J Clin Microbiol 30, 2567-2575.

Kox LFF, van Leeuwen J, Kuijper S, Jansen HM and Kolk AHJ. 1995. PCR assay based on DNA coding for 16S rRNA for detection and identification of mycobacteria in clinical samples. J Clin Microbiol 33, 3225-3233.

Kusunoki S and Ezaki T. 1992. Proposal of Mycobacterium peregrinum sp. nov., nom. rev., and elevation of Mycobacterium chelonae subsp. abscessus (Kubica et al.) to species status: Mycobacterium abscessus comb. nov. Int J Syst Evol Microbiol 42, 240-245. http:// dx.doi.org/10.1099/00207713-42-2-240.

Lescenko P, Matlova L, Dvorska L, Bartos M, Vavra O, Navratil S, No- votny L and Pavlik I. 2003. Mycobacterial infection in aquarium fish. Vet Med 48, 71-78.

Levi MH, Bartell J, Gandolfo L, Smole SC, Costa SF, Weiss LM, Johnson LK, Osterhout G and Herbst LH. 2003. Characterization of Mycobacterium montefiorense sp. nov., a novel pathogenic Mycobacterium from moray eels that is related to Mycobacterium triplex. J Clin Microbiol 41, 2147-2152. http://dx.doi.org/10.1128/ JCM.41.5.2147-2152.2003.

Man SH and Hodgkiss IJ. 1981. Hong Kong Freshwater Fishes. Urban Council, Wishing Printing Company, Hong Kong, $\mathrm{CH}$.

Marcì D, Lo Verde V, Mancuso I, Reale S, Passantino A and Marino F. 2008. Mycobacteriosis in ornamental fish: case reports in Sicily and medical-legal considerations. Vet Res Commun 32, S215S217. http://dx.doi.org/10.1007/s11259-008-9157-4.

Noordhoek GT, Kaan JA, Mulder S, Wilke H and Kolk AHJ. 1995. Routine application of the polymerase chain reaction for detection Mycobacterium tuberculosis in clinical samples. J Clin Pathol 48, 810-814. http://dx.doi.org/10.1136/jcp.48.9.810.

Pate M, Jencic V, Žolnir-Dovc M and Ocepek M. 2005. Detection of mycobacteria in aquarium fish in Slovenia by culture and molecular methods. Dis Aquat Org 64, 29-35. http://dx.doi.org/10.3354/ dao064029.

Rhodes MW, Kator H, Kotob S, van Berkum P, Kaattari I, Vogelbein W, Quinn F, Floyd MM, Butler WR and Ottinger CA. 2003. Mycobacterium shottsii sp. nov., a slowly growing species isolated from Chesapeake Bay striped bass (Morone saxatilis). Int J Syst Evol Microbiol 53, 421-424. http://dx.doi.org/10.1099/ijs.0.02299-0.

Talaat AM, Reimschuessel R and Trucksis M. 1997. Identification of mycobacteria infecting fish to the species level using polymerase chain reaction and restriction enzyme analysis. Vet Microbiol 58, 229-237. http://dx.doi.org/10.1016/S0378-1135(97)00120-X.

Tamura K, Dudley J, Nei M and Kumar S. 2007. MEGA4: Molecular Evolutionary Genetics Analysis (MEGA) software version 4.0. Mol Biol Evol 24, 1596-1599. http://dx.doi.org/10.1093/molbev/ msm092.

Telenti A, Marchesi F, Balz M, Bally F, Böttger EC and Bodmer T. 1993. Rapid identification of Mycobacteria to the species level by polymerase chain reaction and restriction enzyme analysis. J Clin Microbiol 31, 175-178.

Thompson JD, Gibson TJ, Plewniak F, Jeanmougin F and Higgins DG. 1997. The CLUSTAL_X windows interface: flexible strategies for multiple sequence alignment aided by quality analysis tools. Nucleic Acids Res 25, 4876-4882. http://dx.doi.org/10.1093/ nar/25.24.4876.

Whipps CM, Dougan ST and Kent ML. 2007. Mycobacterium haemophilum infections of zebrafish (Danio rerio) in research facilities. FEMS Microbiol Lett 270, 21-26. http://dx.doi.org/10.1111/ j.1574-6968.2007.00671.x.

Whittington RJ and Chong R. 2007. Global trade in ornamental fish from an Australian perspective: the case for revised import risk analysis and management strategies. Prev Vet Med 81, 92-116. http://dx.doi.org/10.1016/j.prevetmed.2007.04.007. 